\title{
The competitive context of strategic orientation and strategy formulation in entrepreneurial and strategic internationalization: Multiple-player and multiple-period games
}

\author{
Hamid Etemad ${ }^{1}$ \\ Published online: 9 September 2019 \\ (C) Springer Science+Business Media, LLC, part of Springer Nature 2019
}

\section{Introduction}

The topics of strategic orientations (SO) and strategy are extensively discussed in the broad literature of the field. However, the importance of the topic deserves even more and this special issue aims to further contribute to our collective understanding of what leads to an effective strategy in internationally oriented entrepreneurial firms. The complex and the competitive context(s) of strategy and their internal-external interactions, for example, are not deeply discussed, the aim of this article is to suggest a gametheoretic frameworks to provide a common competitive context for formulation and implementation of strategy in international entrepreneurship (IE) and to build on the seven papers that follow in order to highlight the impact of the underlying orientations, including strategic orientation (SO), and the importance of resource and priorpreparations for effective formulation and successfull implementation of strategy in order to obtain desired outcomes in entrepreneurial internationalizations.

\section{The context and the path to strategy in entrepreneurial internationalization at a glance}

Consider for example that, the context for application of a typical firm's strategy is competitive markets, within which a firm competes with its competitors there. In international entrepreneurship, that application context is much more complex and the varied local markets of the global markets. Collectively, competitors are involved in highly dynamic multi-location, multi-player and multi-period competitive games, but the local market characteristics, number of competitors and the nature of how each competes, or

Hamid Etemad

hamid.etemad@mcgill.ca

1 McGill University, Montreal, Canada 
plays the competitive game, differ from one competitor to the next, one market to the next and one time period to the next. These complex games, competitive and cooperative, and mostly adaptive (Etemad 2004; Levin 2003, 1998) point to an implicit gaming framework operating in the background; of which we only observe their external outcomes in the international marketplace without the privileged knowledge of the internal dynamics and internal-external interactions that had given rise to them. These concerns are amongst a list of aspects that are not yet clear. Consider, for example, the followings:

(i) Do competitors, or game players, actively, consciously and objectively, consider the competitive gaming context and play their games strategically?

(ii) What are their strategic orientations and how have they come about?

(iii) What is their competitive time-horizon and timings?

(iv) How do they formulate and implement their strategies in different markets and do they consider the impact of one local strategy on other markets?

Logically, there are a host of other related questions and their possible variants across markets and over time periods, but limited time and space impose limitations on in depth discussion of related topics in this article.

As a scholarly exercise, it seems logical to adopt a game-theoretic framework (e.g. Lubell 2013; Bednar and Page 2007; Levin 2003, 1998; Dutton 1995) to provide a richer perspective on a firm's overall and local competitive positions and explore the many potential internal-external interactions across markets, time period and strategies. Accordingly, this preface presumes the implicit presence, if not active application and use, of a game-theoretic framework operating in the background. This presumption allows us to draw lesson from a simple application of such frameworks and explore a range of influential factors in adopting principal strategic orientation (SO) and consequent strategies, including the direct effects of the firms' resources and the internal dynamics of resource allocations in different markets. A deeper understanding of such intangible internal-external interactions, impacting the formulation of strategy underlying the external outcomes in the ongoing complex adaptive games in different local foreign markets, enable us to address a few aspects of such game that deserve our collective scholarly attention, as follows:

The dynamic impact of one market on the other(s) In international entrepreneurship, entrepreneurially oriented firms compete in selective international markets of their choice, where local firms, international SMEs, locally based MNEs, state-owned enterprises and subsidiaries of MNEs would be competing side-by-side. The strategic orientation and international marketing strategies of the firm could exclude some markets for their relatively aggressive, unattractive or unmanageable characteristics from the firm's perspective at the time. Conversely, a firm's combination of aggressive $\mathrm{SO}$ and entrepreneurial orientationsEO (Covin and Miller 2014; Miller 1983) _ can perceive such markets as attractive and enter to win them. Generally, the traditional marketing strategies (e.g. Cadogan 2012) and entrepreneurship (Cadogan et al. 2009) consider not only the size and nature of the existing demand but also the incipient demands, which may present dormant opportunities in need of development and exploitation. The concept of market opportunity and opportunity recognition have been viewed as critical to international entrepreneurship (e.g. Mainela et al. 2015 and JIEN V15, No. 3), as opportunity can translate into incremental values for firms' with higher competitive advantage(s), strength(s) and resources in comparison to 
those of potential competitors in a given market. However, the evaluation of local opportunities neither does explicitly evaluate the presence or absence of the required resources for realizing them, nor does it analyse the restraining impact of limited resources and capabilities in realizing other, and possibly higher, opportunities elsewhere in need of the same resources. The latter may even have added strategic benefits, especially when they can preempts the opportunity with crippling impact(s) on competitors there, which a gametheoretic framework requires to do. The above brief discussion points to the implicit research topic of how does the interactions between adopting a local strategy potentially impact the effectiveness of other strategies in realizing their respective opportunities elsewhere and the subsequent analysis of how such interactive impacts should be considered and evaluated? From a game-theoretic perspective, however, the relatedness (or interrelation) of games suggests that overall cost-benefits of opportunity realization should be an integral part of their respective strategic analysis. Practically, if such inter-relations cannot be fully considered, due to their complexities, constrained resources or time pressures, especially under timid ${ }^{1}$ strategic orientations, at least the potential adverse (or enhancing) impact(s) of an adopted strategy on other markets and opportunities should be considered before implementation and require feedback from others after implementation formulating more pottent startegies in the next periods' set(s) of strategies.

The nature of global competitiveness The competitiveness of firms competing in foreign local markets is partially based on the strategic deployment of their distinct home-based advantages (Porter 1980, Dess and Davis 1984; Powell 2001) not available to competitors, including public subsidies or assistance, privileged access to distinct national or regional resources ${ }^{2}$ and use of national $R \& D$, amongst others. Some local firms may also have exclusive access to their parent's advantages, capabilities and resources, such as firm-specific advantages (FSA-Dunning 1988, Rugman 1986), the parent's internal global markets (Buckley and Casson 1976, 2009) and network (Johanson and Mattsson 1988), worldwide learning (Easterby-Smith et al. 2000, Crossan et al. 1999, Argyris and Schön 1995, Nonaka and Takeuchi 1995), the accumulated experiences of sister subsidiaries and the economies of scale and scope advantages of their network members, including sister operations elsewhere. ${ }^{3}$ Although the resource-based view (RBV) of the firm (Barney 2001, 1991; Grant 1991; Peteraf 1993; Wernerfelt 1984), core competencies and capabilities (Prahalad and Hamel 1999; Teece et al. 1997), the traditional theories of internationalization (Dunning 1988, Buckley and Casson 1976, 2009, Rugman 1986, Johanson and Vahlne 2009, Hymer 1976) and multinationals (Dunning 2000) have provided invaluable insights to the use of such resources and how they can be potentially deployed, their respective interactive impacts are not yet fully discussed. Even the MNE's subsidiaries do not take full

\footnotetext{
${ }^{1}$ This term is used in contrast to the term "aggressive" SO used earlier. Alternatively, one could use narrow versus broad and encompassing SOs.

2 The example of Hydro Quebec (provincial government-owned electricity provider) proving inexpensive and environmentally clean electricity contributes to the competitiveness of firms, local and international, operating in the Province of Quebec on at least two fronts: the low cost of using energy and also producing goods and services in an environmentally sensible manner. In an environment with "cap and trade" regulations, the added advantage of such operations is in generating a lot of tradable credits that environmentally harmful operations would willingly buy.

${ }^{3}$ Internal market of integrated firms, such as IKEA, produced their own basic supplies and sold through their own internal market giving local operations a distinct advantage not available to others.
} 
advantage of other subsidiaries' under-utilized resources or capabilities, partly due to insufficient information, complexity of the inter-subsidiary transactions, narrow perspectives and incomplete information due insufficient measurement metrics. The implication of the above resource deployment issues, especially in resource constrained SMEs, are profound and in need of further elucidation, parts of which are discussed below.

The impacts of entrepreneurs and entrepreneurial orientations Generally, strategic orientation is a set of principles reflecting the core of corporate orientation, thinking and values. In smaller entrepreneurial firms, strategic orientation reflects the entrepreneurial and strategic orientation of their entrepreneur-founders, or small number of decision makers in the firm's top management team (TMT). In turn, the thinking of the firm's managers, or their entrepreneurial orientation (Covin et al. 2006; Lumpkin and Dess 1996, 2001 ; Miller 1983, 2011), based on their state of information and forecast of potential opportunities and threats at the time, influences their approach and the path of their strategy formulation(s) over time for attaining their objectives and deflecting competitive attacks or impediments at the same time. The extent of their EO in general, and its aggressive intensities in particular, are bound to affect the effectiveness of their strategy's implementation. Firm's constrained resources may rule-out the adoption of certain high-cost strategies, regardless of associated cost-benefit consideration. Entrepreneurs' or TMT's effectuation orientation (Sarasvathy 2001) may transform their view toward a constrained optimization, as opposed to aiming to maximize effectiveness of their strategy in obtaining better and higher outcome. The noteworthy point is that, most INVs and Born Globals suffer from constrained resources, especially in the earlier stages of their life cycle (Etemad 2018, 2017), when the effect of competitors' strategic attacks could be highly damaging. Such threats would be larger when these firms' entry to international markets is disruptive (Bower and Christensen 1995) in the shorter term and possibly destructive in the longer term, if and when it is allowed to proceed uninterruptedly. As it is much easier to stop a smaller firm's disruptive strategies earlier on, the strategic logic will dictate that the larger, richer and entrenched firms to interrupt such firms' progress, if not stop them fully, as quickly and aggressively as possible before their disruptions become damaging to them. This argument also supports the other relatedness topics pointed out earlier.

The impact of information Information affects strategy formulation and implementation in few significant ways. For example, information regarding the consumers' reaction to a firm's alternative variations of its principal strategy is of critical importance, as the firm's performance in terms of gaining (or loosing) market share and generating incremental (or reduced) revenues depend on its consumers' behaviour in response (or reaction) to the firm's unfolding strategy in comparison to those of others. While the firm is incapable of learning about competitors' planned strategies, it is in a strong position to draw on a sample of its own and other not committed customers to generate relatively reliable information regarding their potential response to its own and others' competitive strategies for developing an expectation of its performance prior to launching a given strategy. In contrast, generating similar information and predictions about competitors is likely to be much more difficult, more costly and less reliable than ideal. Such information, however, would be highly valuable for enabling the firm to 
formulate potent counter-strategies to deflect competitors' damaging strategic actions. Without the benefits of such information, the firm would be playing a game of chance, if not gambling. This discussion also point to the critical importance of a proper measurement metric (or information agenda) for generating potent and reliable information in a solid information infrastructure for formulating effective strategies. The presence of such strategic pre-requisites is enabling and their absence could expose the firm to risk, uncertainty and their associated harms.

Collecting such information in or for foreign markets is exceedingly more difficult than those in the firm's local and national markets, thus making international marketing strategies highly vulnerable to harmful, and possibly, hostile attacks in foreign markets, where competitors have much richer information - e.g. the home markets of entrenched local competitors, where they have location-specific advantages as well. Although most competitors suffer from similar asymmetric, relatively insufficient and unreliable information, larger, older and more resourceful firms can use their resources and marketposition to acquire the requisite information for formulating a more potent strategic action than their smaller counterparts, especially in markets in which they have been a dominant player.

The impact of evaluation metrics As indicated earlier, a firm's breadth of measurement matrix not only is a prerequisite to the formulation of potent strategy but also is necessary for assessing its effectiveness in order to improve upon them overtime as a firm learns increasingly more about its consumers, competitors, markets and their respective environments. Given that INVs and BGs compete with different competitors in different markets, a firm's global measurement metrics and database matrix need some degree of central coordination to avoid the development of vulnerable strategic orientation and strategies anywhere. Logically, such central coordination may be practically difficult for embryonic INVs and BGs, but vulnerable exposures need to be covered somehow to avoid potentially harmful attacks anywhere. This argument points to the importance of internationalizing firm's preparations prior to internationalization, which depend highly on the extent of support it receives earlier-on in its life cycle. Information structure seems to be as important as the financial structure in firms aspiring to internationalize successfully earlier than later-on. Etemad (2019) has called such prudent investments in embryonic start-ups as "patrimonial heritage" that gives the young firms the necessary competencies and resources in general and potent information in particular, in order to deflect untoward actions of others and enable them to grow successfully. Naturally, such investments extend beyond financial and human capital to a solid R\&D and information infrastructures to enable informed and intelligent strategic actions, amongst others.

\section{Conclusion and implications}

This article began with an examination of the competitive context for formation of international strategic orientation, formulation and implementation of strategy in entrepreneurially oriented enterprises, such as INVs, Born Globals and early internationalizing firms. After a brief examination of what such firms encounter, a game-theoretic framework was proposed to enable them to collect information for 
assessing and incorporating the complexities of multi-location (i.e. active in a number of international markets), multi-players (i.e. active competitors at home and in international markets) and multi-periods (i.e. competing actively overtime) of competitive games into their strategy formulations for achieving their goals and deflecting detracting and harmful strategic actions of others.

The strong entrepreneurial orientation in most of these young firms leads them to adopt a degree of competitive aggressiveness, innovativeness, pro-activeness and risktaking, amongst others, that in part leads to their strategic orientation, which propels them forward in the external marketplace by the formulation of potent strategies and implementing them effectively. Logically, these externally observable outcomes stem from their internal counterparts that are collectively adjusted for, or constrained by, the external conditions and consequently reveal the outcomes of strategies that these firms had adopted and implemented. Viewed differently, the components of firm's entrepreneurial and strategic orientations are the foundations for formulation and implementation of a strategic variant of choice for a market and time period, as opposed to others, against competitors. Therefore, what competitors and others observe externally are reflection of the internal entrepreneurial and strategic attributes that relate to, and are judiciously adjusted for, the state of either perceived (when objective information is lacking) or true (when the measurement metrics provides objective measures) information regarding external conditions, including the behavioural characteristics of competition, collaborators, complementing agents, competitors and consumers. It is logical to ask if entrepreneurial firms' aggressiveness and risk-taking orientations lead them to view strategic competition closer to game of chance (or a gamble) than a well-formulated strategic game with acceptable probability distribution attached to potential outcomes. Regardless of such nuances, the firms' participation in a multi-location and multi-player game must be successful in the long run (i.e. over multi-periods) to justify entrepreneurs to continue playing. One inevitable conclusion is that entrepreneurial firms must aim at winning more meaningful games over time to avoid insolvency and eventual demise.

The implications of the above discussions are equally rich and compelling. Although a selective list of influential issues was already discussed, there is a need for the firm, its strategic managers and their overall support system to coordinate in order to ensure that objectively solid strategic foundations and reliable information support the firm's competitive strategies. The clear lesson is that even small weaknesses may provide beachheads for potentially crippling competitive attacks that need to be systematically plugged and removed as they are discovered. Conversely, objective information may expose other firms' weaknesses and vulnerabilities as strategic opportunities for launching damaging strategies against them.

Finally and on a personal note, I would like to express my gratitude on behalf of the Journal of International Entrepreneurship to the guest editors of this special issue peering into the inner dynamic of entrepreneurial firms, such as INVs and Born Globals, amongst others. Drawing upon the arguments presented above and in the seven articles of this special issue, strategically oriented firms are not logically willing to easily divulge information about the internal foundations of their strategy formulations for the potential damages they can cause, which makes it difficult to understand what had truly underlied what is observable in the marketplace. However, the articles of this special issue reveal insightful information about their focal firms' internal orientations and strategies. Therefore, I invite the readers and scholars to take up the scholarly 
challenges highlighted in this special issue and contribute to the further adoption and development of potent strategies in a context based on multi-player, multi-market and multi-period gaming frsmework . The Journal of International Entrepreneurship welcomes article that peer into inner dynamic of strategy formation and pry it open for the benefits of entrepreneurial firms and the society as a whole.

\section{References}

Argyris C, Schön D (1995) Organizational learning: theory, method and practice. Addison-Wesley, New York

Barney J (1991) Firm resources and sustained competitive advantage. J Manag 17(1):99-120. https://doi. org/10.1177/014920639101700108.ISSN0149-2063

Barney JB (2001) "Is the resource-based view" a useful perspective for strategic management research? Acad Manag Rev 26(1):102. https://doi.org/10.5465/AMR.2001.4011938

Bednar J, Page S (2007) Can game(s) theory explain culture? The emergence of cultural behavior within multiple games. Ration Soc 19(1):65-97

Bower JL, Christensen CM (1995) Disruptive technologies: catching the wave, HBR January-February 1995. pp 43-53. https://doi.org/10.1016/S0048-7333(99)00055-4

Buckley PJ, Casson MC (1976) The future of the multinational enterprise. Macmillan, London [Basingstoke, Hants: Palgrave Macmillan, 25th Anniversary ed. 2001], 112 pp.

Buckley PJ, Casson MC (2009) The internalisation theory of the multinational Enterprise: a review of the progress of a research agenda after 30 years. J Int Bus Stud 40(9):1563-1580

Cadogan JW (2012) International marketing, strategic orientations and business success. Int Mark Rev 29(4): 340-348

Cadogan JW, Kuivalainen O, Sundqvist S (2009) Export Market-Oriented Behavior and Export Performance: Quadratic and Moderating Effects Under Differing Degrees of Market Dynamism and Internationalization. J Int Mark 17 (4):71-89

Covin JG, Miller D (2014) International entrepreneurial orientation: conceptual considerations, research themes, measurement issues, and future research directions. Enterp Theory Pract 38(1):11-44

Covin JG, Green KM, Slevin DP (2006) Strategic process effects on the entrepreneurial orientation-sales growth rate relationship. Entrep Theory Pract 30(1):57-81

Crossan MM, Lane HW, White RE (1999) An organizational learning framework: from learning to institution. Acad Manag Rev 24:522-537

Dess GG, Davis PS (1984) Porter's (1980) generic strategies as determinants of strategic group membership and organizational performance. Acad Manag J 27(3):467-488

Dunning JH (1988) The eclectic paradigm of international production: a restatement and some possible extensions. J Int Bus Stud:1-31

Dunning JH (2000) The eclectic paradigm as an envelope for economic and business theories of MNE activity. Int Bus Rev 9(2):163-190

Dutton WH (1995) The ecology of games and its enemies. Commun Theory 5(4):379-392

Easterby-Smith M, Crossan M, Niccolini D (2000) Organizational learning: debates past, present and future. J Manag Stud 37(6):783-796. https://doi.org/10.1111/1467-6486.00203

Etemad H (2004) International entrepreneurship as a dynamic adaptive system: towards a grounded theory. J Int Entrep 2(1 and 2):5-59

Etemad H (2017) Towards an emerging evolutionary life-cycle theory of internationalized entrepreneurial firms: from Born Globals to borderless firms? J Int Entrep 15:111-120. https://doi.org/10.1007/s10843017-0204-5

Etemad H (2018) Early strategic heritage: the carryover effect on entrepreneurial firm's life cycle. J Int Entrep 16:441-455. https://doi.org/10.1007/s10843-018-0240-9

Etemad H (2019) Revisiting interactions of entrepreneurial, marketing, and other orientations with internationalization strategies. J Int Entrep 17(1):1-18

Grant RM (1991) The resource-based theory of competitive advantage: implications for strategy formulation. Calif Manag Rev 33(3):114-135

Hymer SH (1976) The international operations of national firms: a study of direct foreign investment, [MIT $\mathrm{PhD}$ dissertation, 1960] Cambridge: MIT Press 
Johanson, J and Mattsson, LG (1988) Internationalisation in industrial systems - a network approach, in Hood and Vahlne (eds): Strategies in Global Competition, Croom Helm 287-314

Johanson J, Vahlne J-E (2009) The Uppsala internationalization process model revisited: from liability of foreignness to liability of outsidership. J Int Bus Stud 40(9):1411-1431

Levin SA (1998) Ecosystems and the biosphere as complex adaptive systems. Ecosystems 1(5):431-436

Levin SA (2003) Complex adaptive systems: exploring the known, the unknown and the unknowable. Bull Am Math Soc 40(1):3-20

Lubell M (2013) Governing institutional complexity: the ecology of games framework. Policy Stud J 41(3): 2013. https://doi.org/10.1111/psj.12028

Lumpkin GT, Dess GG (1996) Clarifying the entrepreneurial orientation construct and linking it to performance. Acad Manag Rev 21(1):135-172

Lumpkin GT, Dess GG (2001) Linking two dimensions of entrepreneurial orientation to firm performance: the moderating role of environment and industry life cycle. Journal of Business Venturing 16, 429-451

Mainela T, Puhakka V, Servais P (2015) Boundary crossing for international opportunities. J Int Entrep 13(3): 173-185. https://doi.org/10.1007/s10843-015-0158-4

Miller D (1983) The correlates of entrepreneurship in three types of firms. Manag Sci 29(7):770-792

Miller D (2011) Miller (1983) revisited: a reflection on EO research and some suggestions for the future. Entrep Theory Pract 35(5):873-894

Nonaka I, Takeuchi H (1995) The knowledge creating company. Oxford University Press, New York

Peteraf MA (1993) The cornerstones of competitive advantage: a resource-based view. Strateg Manag J 14(3): 179-191. https://doi.org/10.1002/smj.4250140303

Porter ME (1980) Competitive strategy: techniques for analyzing industries and competitors. Free Press, New York

Powell TC (2001) Competitive advantage: logical and philosophical considerations. Strateg Manag J 22(9): 875-888. https://doi.org/10.1002/smj.173

Prahalad CK, Hamel G (1999) The core competence of the corporation. Harv Bus Rev 68(3):79-91

Rugman AM (1986) "New Theories of the Multinational Enterprise: An Assessment of Internalization Theory". Bull Econ Res 38 (2): 101-118. https://doi.org/10.1111/j.1467-8586.1986.tb00208.x

Sarasvathy SD (2001) causation and effectuation: toward a theoretical shift from economic inevitability to entrepreneurial contingency. Acad Manag Rev 26(2). https://doi.org/10.5465/amr.2001.4378020

Teece D, Pisano G, Shuen A (1997) Dynamic capabilities and strategic management. Strateg Manag J 18(7): 509-533. https://doi.org/10.1002/(sici)1097-0266(199708)18:7<509::aid-smj882>3.0.co;2-z

Wernerfelt B (1984) A resource-based view of the firm. Strateg Manag J 5(2):171-180. https://doi.org/10.1002 /smj.4250050207

Publisher's note Springer Nature remains neutral with regard to jurisdictional claims in published maps and institutional affiliations. 